\title{
Economic growth and income distribution implications of public spending and tax decisions**
}

\author{
ZSOLT DARVAS $^{1,2 *}$ ] \\ ${ }^{1}$ Bruegel, Brussels, Belgium \\ ${ }^{2}$ Corvinus University of Budapest, Budapest, Hungary
}

Received: November 26, 2019 • Revised manuscript received: October 1, 2020 • Accepted: November 2, 2020

Published online: November 7, 2020

(c) 2020 The Author(s)

\begin{abstract}
Both the level and composition of public expenditures and revenues have implications for economic development, as argued by the 'fiscal multiplier' and the 'quality of public finance' literature. Public finance decisions also influence the distribution of income. By reviewing the literature, I argue for a fair distribution of income as reflected in low income inequality, not particularly because of the impact of income inequality on long-term growth (which is a controversial issue), but primarily because income inequality typically implies inequality of opportunity. European Union countries have very diverse public finance structures and different levels of effectiveness, and there is room for improvement in growth and equality impacts in all countries. A general guideline would be that the most effective approach comprises progressive taxes and inheritance taxes, spending on education, health and public infrastructure, and better government effectiveness. At the height of the 2008 global and the subsequent European financial and economic crises, the fiscal consolidation strategies of EU countries largely relied on cutting public investment and social spending (except pensions), which is the opposite of what is suggested in the literature. Better fiscal rules and good fiscal institutions are needed to safeguard growth- and distribution friendly expenditures in a crisis.
\end{abstract}

\section{KEYWORDS}

taxation, public pending, economic growth, income inequality

JEL CODES

D63, H2O, H50, 040

\footnotetext{
*Corresponding author. Email: zsolt.darvas@bruegel.org

**The first version of this paper was prepared for the Budapest Public Finance Seminar 2019 on 'Growth implications of state budget income and expenditure structure', 23 May 2019, Budapest, Hungary, organised by the Hungarian State Treasury. I thank Boris Cournède and conference participants for useful comments and suggestions.
} 


\section{INTRODUCTION}

Extensive literature shows that both the level and composition of public expenditures and revenues have implications for economic development. There are two main strands of the literature. The discussion on the short-term impacts of public finance decisions was especially active after the 2008 global and the subsequent European financial and economic crises, when several countries implemented fiscal consolidation strategies. This literature is frequently referred to as the 'fiscal multiplier' discussion (e.g. Auerbach - Gorodnichenko 2012; Blanchard - Leigh 2013). The other main relevant theme of the literature focuses on the longer-term impacts of the public finance structure on the level, or even the growth, of the economy, which can be referred to the 'quality of public finance' discussion (e.g. Barrios and Schaechter, 2008; European Commission 2012). The composition of, and changes in, tax revenues have the greatest impact when taxes are paid. Thereby, tax compliance and the broadness of tax bases are similarly important issues, as well as the effectiveness of the public sector, which underpins all public sector actions.

In this article I combine public finance structure and effectiveness issues, which can influence aggregate economic growth, with their impacts on the distribution of income. Striving for fairness in income distribution is crucial for societies to be stable and for citizens not to feel disenchanted. The concept of 'inclusive growth' provides a conceptual framework to analyse the social implications of economic growth. Growth is considered inclusive if it creates opportunities for all segments of the population and shares them fairly (OECD 2020a). To understand inclusive growth, we must first understand inequality, which has two crucial categories. One is the inequality of opportunity in access to education, jobs, healthcare, finance or the judicial system, for example. The other is inequality of outcomes, such as income, wealth, health and educational attainment.

While the level of income inequality in European Union (EU) countries is generally lower than in other advanced and emerging countries, there are large differences between EU member states and recent changes in the income distribution cannot always be regarded as 'fair'. For example, as Darvas (2019) shows, the very rich in Bulgaria have doubled their real incomes from the mid-2000s to the mid-2010s, while the poorest five percent of the society benefitted from an only twenty percent increase - and from so much lower levels. In contrast, in Germany, the poorest five percent benefitted from faster income growth than the richest five percent during the same period. I therefore also consider the reasons why income distribution developments matter, and how public finance structure decisions can influence the distribution of income.

The rest of the article is organised as follows. Section 2 highlights the importance of a fair distribution of income. Section 3 scrutinises the diversity of fiscal structures of EU member states. Section 4 surveys the literature on the growth and distributional impacts of public spending and tax decisions. Section 5 offers three concluding remarks.

\section{WHY DOES THE FAIR DISTRIBUTION OF INCOME MATTER?}

In our reading of the vast academic literature (Darvas - Wolff 2016), the main reason for the importance of a fair income distribution is not its impact on long-term economic growth. The literature about the impact of income inequality on long-term growth is inconclusive: about half of the studies we surveyed conclude that income inequality reduces economic growth, but about a quarter of the works conclude that it is in fact good for growth, while another quarter conclude that the impact is not significant. These altering results originate not just from different 
methodologies and empirical samples, but also from theories, which have diverse predictions about the impact of income inequality on growth.

Greater inequality and financial market imperfections might reduce the capacity of lowincome households to invest in education, lowering economic growth (Galor - Zeira 1993). Under-investment in human capital by poorer segments of society might reduce social mobility and adequate allocation of talent across occupations (Banerjee - Newman, 1993; Fershtman et al. 1996; Owen - Weil 1998). Greater inequality might also reduce growth if it leads to political instability and social unrest (Alesina - Perotti 1996; Keefer - Knack 2002). If inequality becomes unacceptable for voters, they might insist on higher taxation and regulation, as well as mistrust businesses, reducing incentives to invest (Alesina - Rodrik 1994; Bertola 1993).

On the other hand, greater inequality could increase growth if it provides incentives to work harder and take risks in order to capitalise on high rates of return (Mirrlees 1971). Large differences in rates of return for education might encourage more people to seek education. Greater inequality could foster aggregate savings and capital accumulation, because the rich save relatively more (Bourguignon 1981; Kaldor 1957). Fuentes and Leamer (2019) provide theory and evidence that worker effort has played an important role in the increase in income inequality in the United States between 1980 and 2016.

These inconclusive theoretical predictions and empirical results do not allow drawing a firm conclusion on the impact of income inequality on economic growth. ${ }^{1}$ But there are several other economic, social and political issues which imply that high levels of income inequality should be avoided.

Among economic issues, a high level of inequality might lead households to rely on debt financing to maintain living standards, a factor that might have been a significant driver of the housing boom in the pre-crisis period in the US, and the consequent bust (Rajan 2011; Van Treeck 2014). Greater inequality could reduce the level and duration of periods of growth (Berg et al. 2018), and could also be linked to greater financial instability (Skott 2013; Vandemoortele 2009). For the euro area, Darvas and Wolff (2014) showed that in countries with greater inequality, households tended to borrow more prior to the crisis, resulting in more subdued consumption growth during the crisis. The resulting high private debt, high unemployment, poverty and more limited access to education undermine long-term growth and social and political stability.

Perhaps the most important reason for a political goal of reducing income inequality is that higher inequality is found to be associated with less inter-generational (or social) mobility: the children of poor families tend to stay poor, while the children of rich families tend to stay rich (Andrews - Leigh 2009; Corak 2013). ${ }^{2}$ That is, greater inequality tends to be associated with a greater likelihood that economic advantage/disadvantage will be passed from parents to their

\footnotetext{
${ }^{1}$ There are also some works that can rationalise the diverging empirical results and theoretical predictions on the relationship between income inequality and economic growth (or economic efficiency). For example, Anderson and Maibom, 2016 find that countries that are at the frontier of economic performance and income equality face a trade-off between efficiency and equity, but most countries are below the frontier and therefore they can improve both. Aghion et al., 2015 find a significant positive correlation between top income inequality and growth in those US states which are close to the most productive US state ('frontier growth'), but negative correlation between top income inequality and non-frontier growth.

${ }^{2}$ For example, in some Nordic countries (Finland, Denmark, Norway), where income inequality is relatively low, social mobility is relatively high. In contrast, in countries where income inequality is relatively high (Italy, United Kingdom, United States), social mobility is relatively low. While there are differences in intergenerational mobility in different regions in each country, Bratberg et al. (2016) found that the most socially mobile region in the US is substantially less mobile than the least mobile regions of Norway and Sweden.
} 
children. By studying wealth inequality in Europe, Darvas and Midões (forthcoming) find that the average gain in wealth due to inheritance is greater than the gain associated with having a university degree instead of primary school education, highlighting the crucial role of family background and that education might not fully compensate for that. While 'fairness' is a complex concept, whatever definition is adopted, it cannot be regarded as 'fair' that two persons reach different outcomes when they have the same talent and make the same effort, just because of their different family backgrounds. Inequality arising from different levels of effort or luck should be welcomed, but inequality from unequal opportunity should not.

High income inequality can also influence politics by boosting protest votes in referenda and elections. Darvas (2016) concluded that income inequality boosted the vote for Brexit in the UK's EU membership referendum in June 2016. Darvas and Efstathou (2016) concluded that income inequality boosted the vote for Donald Trump in the 2016 US presidential election. ${ }^{3}$ These results can be regarded as protest votes against the status quo, with profound political implications.

\section{THE DIVERSITY OF FISCAL STRUCTURES OF EU MEMBER STATES}

There is a great variation both in the size and the composition of general government budgets in the EU (Fig. 1). The size in 2018 varied between 26 percent of GDP in Ireland ${ }^{4}$ to 56 percent of GDP in France, while the cross-country average is 43 percent. Social spending relative to GDP is particularly high in France, Belgium and Germany, but rather low in Ireland, Malta, Latvia and Romania. Gross investment as a share of GDP is far the highest in Cyprus and Hungary, but low in Ireland, Spain and Portugal. Belgium and France provide the most subsidies relative to GDP, while the compensation of public sector employees is clearly highest in Denmark, followed by Sweden, France, Finland and Belgium. Irish, German and Dutch public sector employees receive the least as a share of GDP. These large differences likely reflect different societal preferences for the size of the public sector and corresponding tax rates.

Interest spending relative to GDP is highest in Italy, followed by Portugal, Greece ${ }^{5}$ and Hungary. Estonia hardly pays any interest due to its very low public debt level (gross public debt was only 8 percent of GDP in 2018). Sweden and Luxembourg also pays less than half a percent of GDP on interest, and there are seven countries that pay between half and one percent of GDP.

There are also huge differences in tax rates across the EU. The so-called 'implicit tax' rate measures the effective average tax rate, and thereby incorporates the impacts of tax rates and the broadness of the tax base, including various exemptions. The differences in consumption tax rates (Fig. 2), labour tax rates (Fig. 3), corporate income tax rates (Fig. 4) and environmental tax rates (Fig. 5) are enormous. In 2018, the implicit consumption tax ranged from 14 percent in

\footnotetext{
${ }^{3}$ These studies on the Brexit and Trump votes controlled for various other factors influencing voters, including age, education, income, unemployment, location, immigration and race.

${ }^{4}$ The Irish GDP is significantly increased due to profits of foreign companied booked in Ireland. Therefore the last column of Fig. 1 shows spending as a share of GNI in Ireland, which is 33 percent, still the lowest among EU countries.

${ }^{5}$ The data reported correspond to accrual accounting, but on a cash-flow basis Greece pays much lower interest, because most of interest due to European Financial stability Facility (EFSF) loans are deferred and the accumulated value of these deferred interest will be added to the stock of outstanding public debt in 2022 .
} 


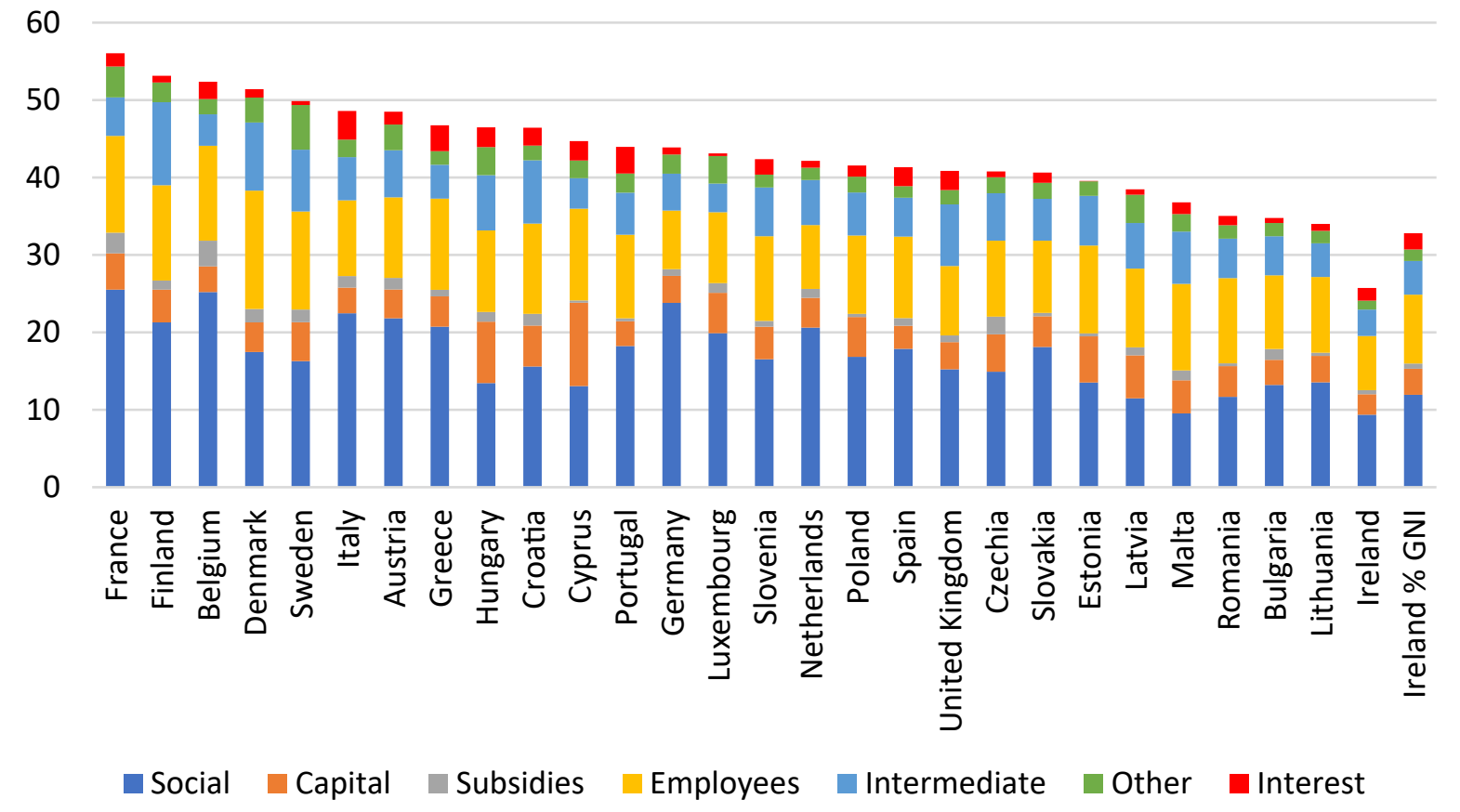

Fig. 1. General government expenditures, 2018 (percentage of GDP).

Source: author, based on AMECO.

Notes: All values are expressed as a percentage of GDP, except the last column, which shows percentage of GNI values for Ireland, a country in which GDP is significantly boosted by profits of foreign companies. 'Social' is composed of 'Social benefits other than social transfers in kind' and

'Social transfers in kind supplied to households via market producers'; 'Capital' includes 'Gross fixed capital formation' and 'Other capital expenditure, including capital transfers'; 'Employees' refer to 'Compensation of employees'; 'Intermediate' refers to 'Intermediate consumption'; 'Other' refers to 'Other current expenditure'; 'Interest' refer to the interest paid by the general government on public debt 


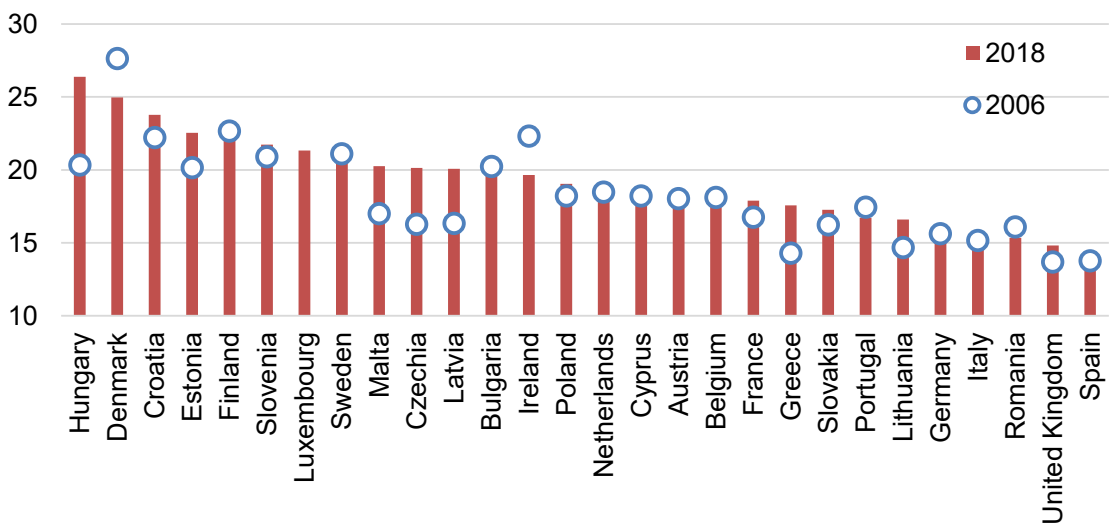

Fig. 2. Implicit tax rate on consumption, 2006 and 2018 (percentage).

Source: author, based on European Commission (2020).

Note: The implicit tax rate on consumption is defined as all consumption taxes divided by the final consumption expenditure of private households on the economic territory (domestic concept)

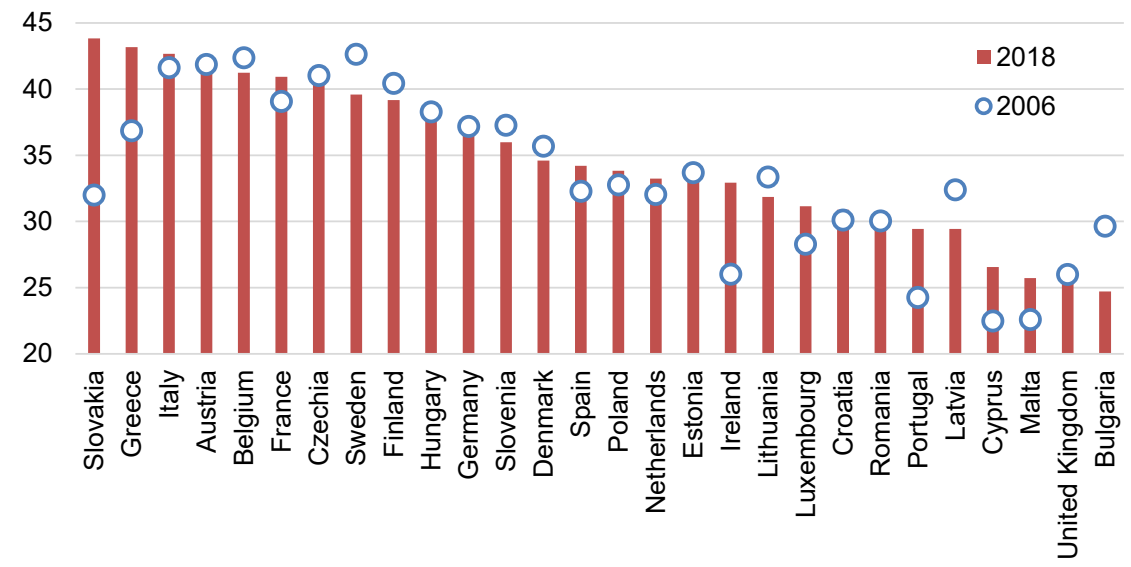

Fig. 3. Implicit tax rate on labour, 2006 and 2018 (percentage).

Source: author, based on European Commission (2020).

Note: The implicit tax rate on labour is defined as the sum of all direct and indirect taxes and employees' and employers' social contributions levied on employed labour income divided by the total compensation of employees. It is calculated for employed labour only (so excluding the tax burden falling on social transfers, including pensions)

Spain to 26 percent in Hungary, labour taxes (including social security contributions paid by both the employer and the employee) ranged from 25 percent in Bulgaria to 44 percent in Slovakia, while energy taxes are 3-times higher in Denmark and Italy than in Hungary, Bulgaria 


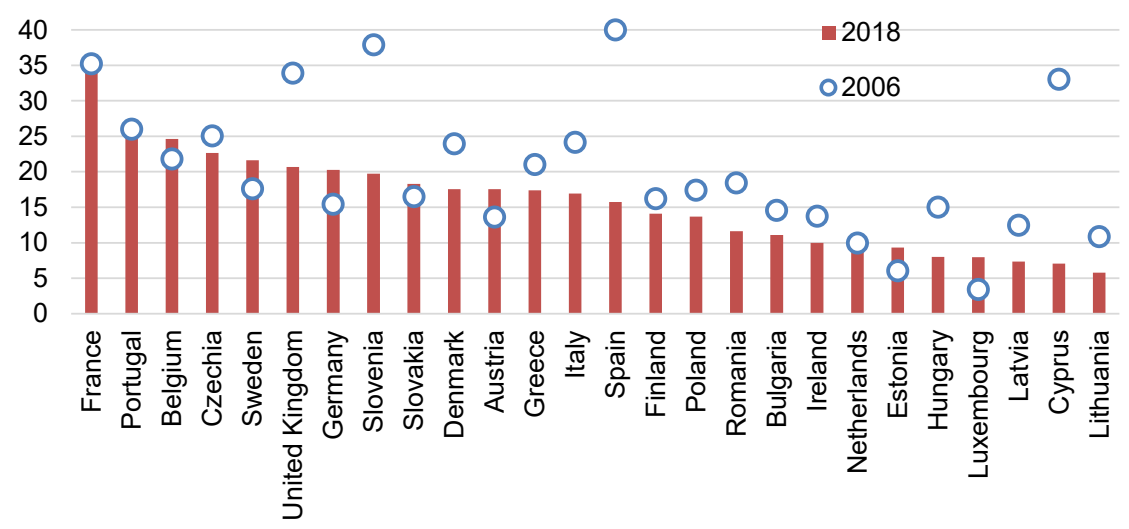

Fig. 4. Implicit tax rate on corporate income, 2006 and 2018 (percentage).

Source: author, based on European Commission (2020).

Note: The implicit tax rate on corporate income is defined as the ratio between revenue from taxes on income/profits of corporations (including holding gains) and all taxable capital and business income of corporations. The numerator comprises taxes raised on corporate income and the denominator is defined as the sum of the net operating surplus and property income balance of the corporate sector. A full definition and description of the methodology can be found in Annex B of European Commission (2018b). This indicator is called the 'traditional' version by European Commission (2018b). There is an alternative 'no dividends' version of this indicator, which excludes all dividends from the denominator, due to the widespread tax exemption of received dividends

and Lithuania. The effective corporate income tax rate is at or below 10 percent in the three Baltic countries, Cyprus, Luxembourg, Hungary, the Netherlands and Ireland, while it is over 35 percent in France.

Low corporate taxation, along with lenient regulation, might create conditions similar to tax havens even within the European Union. By conducting a data-driven approach to identify offshore financial centres (OFCs) based on a dataset covering global corporate ownership networks, in which over 98 million firms are connected through 71 million ownership relationships, GarciaBernardo et al. (2017) concluded that the Netherlands and Ireland (along with the United Kingdom, Switzerland and Singapore) are conduit-OFCs, which are attractive intermediate destinations in the routing of international investments and enable the transfer of capital without taxation. They also find that Luxembourg and Cyprus (along with Malta and 21 non-EU countries) are sink-OFCs, which attract and retain foreign capital via low taxation and lenient regulation.

Since my focus is also on the income distribution implications of public spending and tax decisions, I look at labour taxes for different types of earners based on their income, family status and number of children (Fig. 6). The tax wedge is a measure of the taxes on labour income (including social security contributions) paid by employees and employers, minus family benefits received, as a percentage of the labour costs of the employer. The columns A, B and C in Fig. 6 compare the tax wedge for single persons without a child at 67 percent, 100 percent and 167 percent of average earnings, respectively. Among the six countries included on the chart, in 2019 the tax wedge was progressive in Belgium, France, Germany and Spain, it was almost flat in 


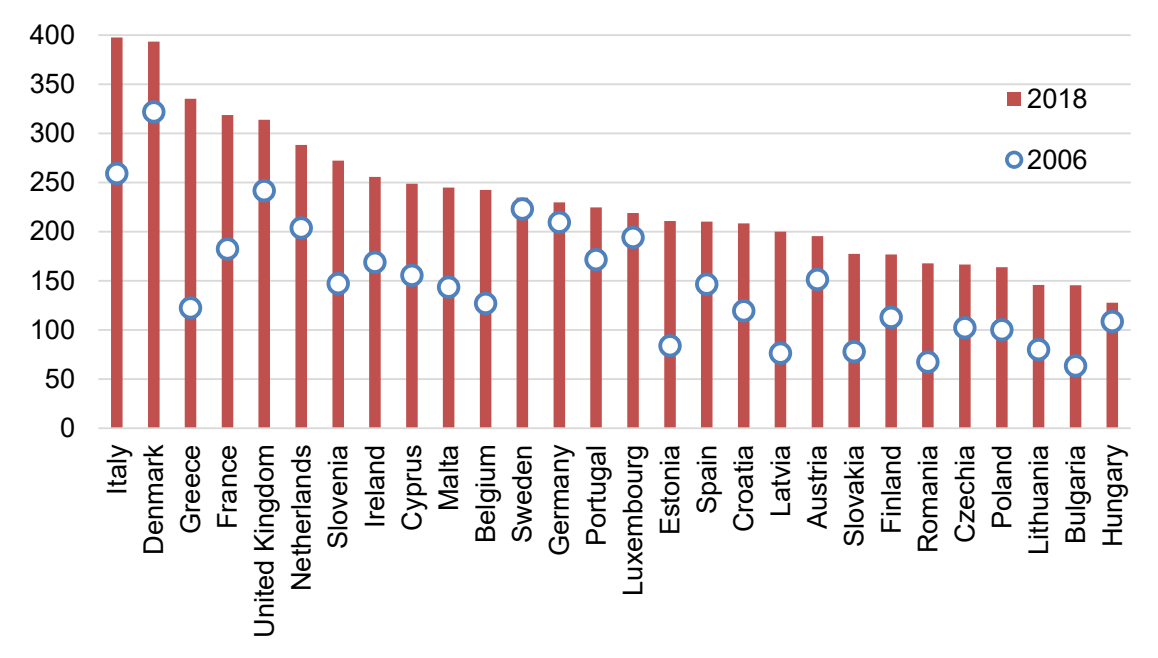

Fig. 5. Implicit tax rate on energy, 2006 and 2018 (energy taxes in euro per tonne of oil equivalent TOE).

Source: author, based on European Commission (2020).

Note: This indicator is defined as the ratio between energy tax revenues and final energy consumption calculated for a calendar year. Energy tax revenues are measured in euro and the final energy consumption as TOE (tonnes of oil equivalent)

Poland and perfectly flat in Hungary. Having two children reduces the tax wedge in all countries, which can be seen by comparing column $\mathrm{D}$ (single person at 67 percent of average earnings, with two children) with column A (single person at 67 percent of average earnings, no child). The reduction is especially stark in Poland, when a single person at 67 percent of average earnings with two children benefits from a negative tax wedge, implying that family benefits received are larger than taxes and social security contributions paid.

The changes since 2005 suggest a general reduction in tax wedges for almost all categories reported on the chart, with the exception of low earners in Hungary, who faced a higher tax wedge in 2019 than in 2005. The Hungarian data also shows that Hungary has changed progressive income taxes to flat taxes, which has particularly benefitted higher-income earners.

Finally, I look at the taxation of property. Unfortunately, the implicit tax rate on property is not calculated, probably due to the difficulties in measuring the value of property, so I report the share of property tax revenue in GDP (Fig. 7). There are again large differences among EU countries. France and the UK collect about 4.5 percent of GDP from property taxes, closely followed by Belgium and Greece, while in $16 \mathrm{EU}$ countries the revenue amounts to 1.2 percent of GDP or less.

The large variation in public expenditure and revenue structures might reflect societal preferences. Nevertheless, whatever amount is collected by the public sector, it should be spent efficiently. Sapir (2006) argued that the efficiency of the Mediterranean social model is low and at the same time inequality levels are high. Darvas and Wolff (2014) corroborate this finding, by showing that most Mediterranean countries, and also some Central and Eastern European and 


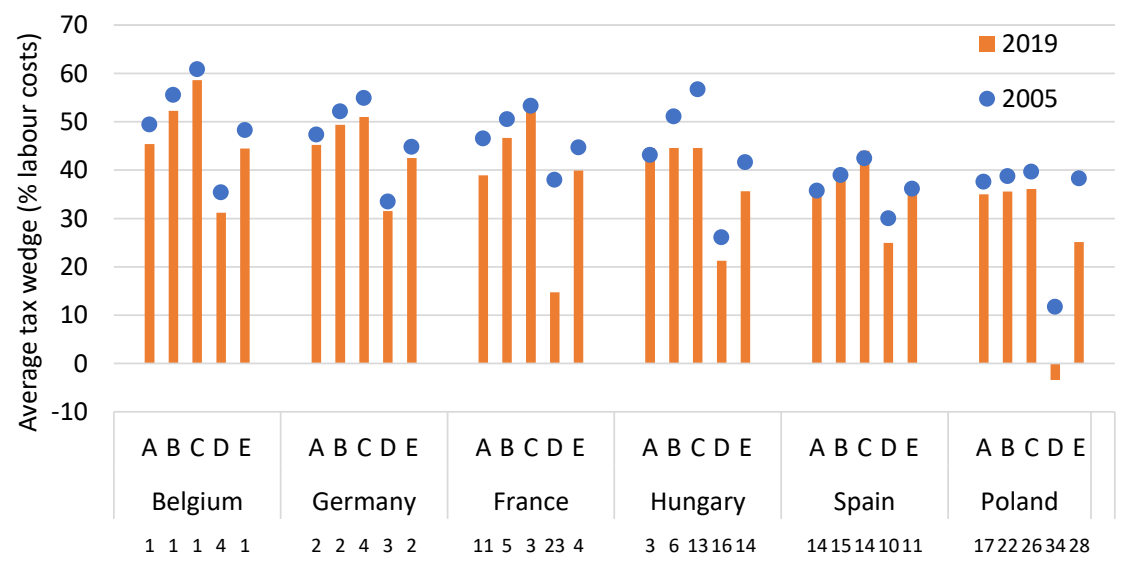

Fig. 6. Tax wedge of different earners, 2005 and 2019.

Source: author, based on OECD (2020b).

Note: The tax wedge is a measure of the taxes on labour income paid by employees and employers, minus family benefits received, as a percentage of the labour costs of the employer. A - Single person at $67 \%$ of average earnings, no child; B - Single person at $100 \%$ of average earnings, no child; C - Single person at $167 \%$ of average earnings, no child; $D$ - Single person at $67 \%$ of average earnings, with two children; E - Two-earner married couple, one at $100 \%$ of average earnings and the other at $67 \%, 2$ children. The numbers below the country names indicate the rank among $\mathbf{3 6}$ countries in $\mathbf{2 0 1 9}$ for each of the earner categories (low number $=$ high tax wedge)

some Western European countries, achieve comparatively lower reductions of income inequality for any given amount of social expenditure and for a given level of average personal income taxes. For example, the share of social expenditure in GDP is similar in Greece, Italy and Finland, but while the Finnish system is able to reduce income-inequality (as resulted by market forces) by more than 45 percent, the Italian and Greek systems can reduce it only by 30 percent. $^{6}$ For countries with less efficient redistribution systems, a reform of the social model would therefore appear to be a promising avenue. It could substantially reduce income inequality with the same level of government spending and taxation, or reduce government spending and taxation without increasing income inequality. For example, Vtyurina (2020) analysed spending reviews for Spain and reported that about $80 \%$ of family benefits are not means-tested, ${ }^{7}$ implying that more well-off households receive a substantial portion of the benefits. Furthermore, there are shortcomings in adequacy and coverage. Better targeting the most vulnerable would make Spanish social spending more effective.

\footnotetext{
${ }^{6} \mathrm{~A}$ caveat is that some social spending might not be targeted at reducing income inequality, but rather at pursuing other social goals.

${ }^{7}$ Means-tested social benefits refer to benefits where entitlement is explicitly or implicitly conditional on the beneficiary's income/wealth.
} 


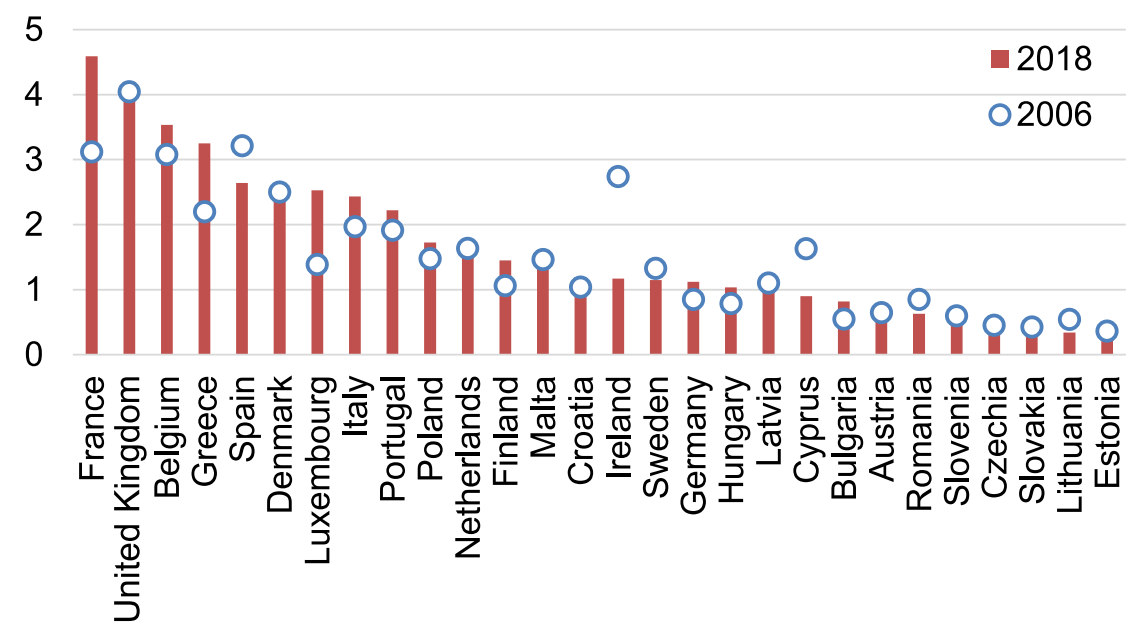

Fig. 7. Property tax revenue, 2006 and 2018 (percentage of GDP). Source: author, based on European Commission (2020)

Last but not least, an effective government is indispensable for public finance decisions to achieve their desired impact. While it is difficult to measure government effectiveness, the World Bank developed a useful indicator among its governance indicators. The indicator reflects perceptions of the quality of public services, the quality of the civil service and the degree of its independence from political pressures, the quality of policy formulation and implementation, and the credibility of the government's commitment to such policies. The indicator draws on various sources and is then standardised, so the world average is zero and the standard deviation is one. Fig. 8 shows that all EU countries but Romania achieved a positive score, yet there are

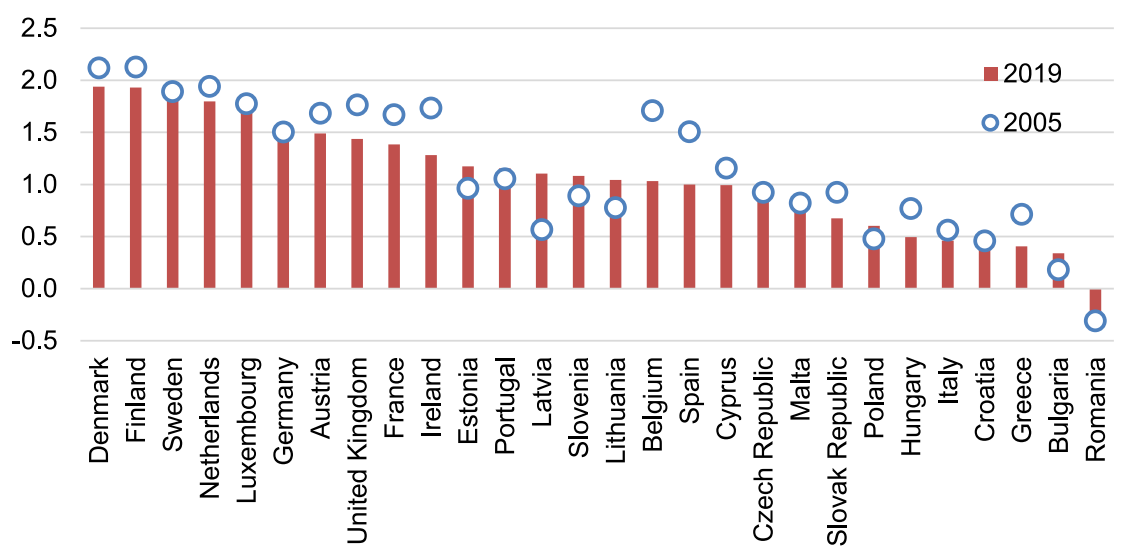

Fig. 8. Government effectiveness, 2005 and 2019.

Source: author, based on World Bank (2020) 
notable differences within the EU. The best performing countries include Northern (Denmark, Finland, Sweden) and Western (the Netherlands, Luxembourg, Germany) European countries, while the worst performers are from Southern and Eastern Europe (Romania, Bulgaria, Greece, Italy, Hungary). Undoubtedly, Southern and Eastern EU countries should take decisive steps to improve their government effectiveness.

\section{GROWTH AND DISTRIBUTIONAL IMPACTS OF FISCAL STRUCTURES}

After reviewing the large variety of public spending and taxing practices across EU countries, I now scrutinise the academic literature on the growth and income distribution implications of public spending and revenue decisions. There has been wide-ranging research on this topic, which is not always conclusive.

A meta-analysis of 42 studies on the impact of taxes on economic growth in OECD countries by Alinaghi and Reed (2018) supports the prediction of theories: tax policies predicted by growth theory to be growth-retarding, such as the use of distortionary taxes to fund unproductive expenditures, are significantly associated with lower economic growth, while tax polices predicted to be growth-enhancing, such as the use of non-distortionary taxes to fund productive expenditures, are significantly associated with higher economic growth. ${ }^{8}$

As regards distortionary/non-distortionary taxes and productive/unproductive expenditures, Alinaghi and Reed (2018) adopt the classification of Kneller et al. (1999). Those taxes are considered distortionary which affect the investment decisions of agents (with respect to physical and/or human capital), creating tax wedges and hence distorting the steady-state rate of growth. Non-distortionary taxation does not affect saving/investment decisions because of the assumed nature of the preference function, and hence has no effect on the rate of growth. In this classification, distortionary taxes are the various kinds of taxes and social security contributions on income and profit as well as taxes on property, while consumption taxes are classified as non-distortionary.

Those public expenditures are considered productive which are included as arguments in the private production function and thereby affect the steady-state rate of growth. If they are not then they are classified as unproductive expenditures. Within this classification, productive public expenditures include general public services, defence, education, health, housing, transport and communication, while unproductive expenditures include social security and welfare expenditure, recreation and economic services.

However, as noted by Alinaghi and Reed (2018), in practice, no tax is truly non-distortionary, so the distinction hinges on the degree to which the allocation of resources is affected. Similarly, there cannot be a clear dividing line between productive and unproductive expenditure. For example, social safety net spending to preserve or even enhance the human capital of the unemployed people should boost growth, while for example more spending on public services might not necessarily improve the efficiency of public administration and thereby cannot be regarded as unambiguously productive.

As regards redistribution, which is related to the size of public budgets, earlier literature typically concluded that more redistribution and larger public budgets are detrimental to

\footnotetext{
${ }^{8}$ Alinaghi and Reed (2018) also report a publication bias in results, whereby there is a preference for estimates that are significant, and/or that accord with theoretical or ideological predispositions in published articles. They correct for this bias.
} 
economic growth, because higher taxes and subsides reduce the incentives to work and invest (Okun 1975). More recently, Jaimovich and Rebelo (2017) conclude that low tax rates have a very small impact on long-run growth rates, but as tax rates rise, their negative impact on growth rises dramatically.

These views are questioned by Berg et al. (2018). They conclude that fiscal redistribution, unless it is extreme, may be a win-win policy because of its equality-inducing effects. They do find some mixed evidence that very large-scale redistribution may have direct negative effects on growth duration, but for non-extreme redistributions, there is no evidence of any adverse direct effect.

A recent comprehensive study by Cournède et al. (2018) presents a very useful analysis of both the growth and distributional impacts of public finance decisions. They consider both the direct impacts (e.g. change in a certain tax rate) and indirect impacts (behavioural change because of the change in a tax rate) of such decisions. In order to provide comparable scenarios, they consider fiscally-neutral changes, such as raising a certain tax rate while cutting all other tax rates proportionally. They present econometric estimates for the effects of public finance structure on real output per capita and the distribution of real household disposable income, which are then combined in simulations to quantify disposable income impacts for each income decile group. Some of their most interesting findings are the following:

- Boosts growth and reduces income inequality: lower tax wedge on low-income earners, higher inheritance and gift taxes, greater government effectiveness;

- Boosts growth, while no significant impact on income inequality: higher public investment, lower public pension expenditure, higher recurrent property taxes, higher quality education, lower corporate income tax;

- Boosts growth and widens income inequality: lower total public spending, lower public subsidies, lower wealth taxes, lower labour tax wedge on above-average income earners;

- No growth impact but reduces income inequality: higher child and family benefits, ${ }^{9}$ lower environmental taxes; however, shifting taxation away from low-paid labour towards environmental taxes can generate economic and distributional benefits, and improve the environment;

- No major impact: value added tax.

Cournède et al. (2018) also note that there are limits to the reallocation of the tax burden from more towards less distortive taxes such as value-added taxes. Many European countries seem close to the point where higher rates reduce revenue by generating significant economic distortions and strong disincentives for compliance. Broadening the tax base and improving collection should be favoured instead.

The need for progressive taxes is also supported by Diamond and Saez (2011), who critically assessed the academic research on optimal taxation. Their three main conclusions are: first, very high earners should be subject to high and rising marginal tax rates on earnings; second, low-income families should be encouraged to work with earnings subsidies, which should then be phased-out with high implicit marginal tax rates; and third, capital income should be taxed.

\footnotetext{
${ }^{9}$ European Commission (2018a: Part III) also concludes that education and health spending, as well as sickness, disability, family and child benefits, significantly reduced income inequality in the EU on average over the period 1980 to 2014 .
} 
The case for inheritance taxes in a theoretical optimal taxation framework is made by Piketty and Saez (2013), who conclude that the optimal tax rate is positive and quantitatively large if the elasticity of bequests to the tax rate is low, bequest concentration is high, and society cares mostly about those receiving little inheritance. In contrast, the optimal tax rate can be negative when society cares mostly about inheritors.

\section{CONCLUDING REMARKS}

Instead of a detailed summary, let me close this article with three key takeaways.

First, public finance structure and effectiveness matter for economic growth and income inequality. The literature provides useful guidelines on the most growth- and equality-friendly composition of taxes and expenditure, and emphasises the need to broaden taxes bases and improve tax compliance.

Second, EU countries have very diverse public finance structures and different levels of effectiveness. While the situation of each country should be analysed considering its special circumstances, there is room for improvement in terms of the growth and equality impacts in all countries. A general guideline would be that there should be progressive taxes and inheritance taxes, spending on education, health and public infrastructure, and better government effectiveness.

Third, despite the conclusions of academic research, at the height of the 2008 global and the subsequent European financial and economic crises, the fiscal consolidation strategies of EU countries largely relied on cutting public investment and social spending, except pensions (see Darvas - Wolff 2016), thereby worsening both the growth outlook and income inequality. Better fiscal rules and good fiscal institutions are needed to safeguard growth- and distribution friendly expenditures in a crisis.

\section{REFERENCES}

Aghion, P. - Akcigit, U. - Bergeaud, A. - Blundell, R. - Hemous, D. (2015): Innovation, Income Inequality, and Social Mobility. VOX - CEPR's Policy Portal. https://voxeu.org/article/innovation-incomeinequality-and-social-mobility, accessed 3 October, 2020.

Alesina, A. - Perotti, R. (1996): Income Distribution, Political Instability, and Investment. European Economic Review 40(6): 1203-1228.

Alesina, A. - Rodrik, D. (1994): Distributive Politics and Economic Growth. The Quarterly Journal of Economics 109(2): 465-490.

Alinaghi, N. - Reed, W. R. (2018): Taxes and Economic Growth in OECD Countries: A Meta-analysis. University of Canterbury Working Papers in Economics 18/09.

Anderson, T. M. - Maibom, J. (2016): The Trade-off Between Efficiency and Equity. VOX - CEPR's Policy Portal. https://voxeu.org/article/trade-between-efficiency-and-equity, accessed 3 October, 2020.

Andrews, D. - Leigh, A. (2009): More Inequality, Less Social Mobility. Applied Economics Letters 16(15): 1489-1492.

Auerbach, A. J. - Gorodnichenko, Y. (2012): Measuring the Output Responses to Fiscal Policy. American Economic Journal: Economic Policy 4(2): 1-27.

Banerjee, A. V. - Newman, A. F. (1993): Occupational Choice and the Process of Development. Journal of Political Economy 101(2): 274-298. 
Barrios, S. - Schaechter, A. (2008): The Quality of Public Finances and Economic Growth. DirectorateGeneral for Economic and Financial Affairs Economic Papers 33. https://ec.europa.eu/economy_finance/ publications/pages/publication13101_en.pdf, accessed 3 October, 2020.

Berg, A. - Ostry, J. D. - Tsangarides, C. G. - Yakhshilikov, Y. (2018): Redistribution, Inequality, and Growth: New Evidence. Journal of Economic Growth 23(3): 259-305.

Bertola, G. (1993): Factor Shares and Savings in Endogenous Growth. The American Economic Review 83(5): 1184-1198.

Blanchard, O. J. - Leigh, D. (2013): Growth Forecast Errors and Fiscal Multipliers. American Economic Review 103(3): 117-120.

Bourguignon, F. (1981): Pareto Superiority of Unegalitarian Equilibria in Stiglitz' Model of Wealth Distribution with Convex Saving Function. Econometrica 49(6): 1469-1475.

Bratberg, E. - Davis, J. - Mazumder, B - Vaage, K. - Nybom, M. - Schnitzlein, D. (2016): A Comparison of Intergenerational Mobility Curves in Germany, Norway, Sweden and the US. The Scandinavian Journal of Economics 119(1): 72-101.

Corak, M. (2013): Income inequality, equality of opportunity, and intergenerational mobility. The Journal of Economic Perspectives 27(3): 79-102.

Cournède, B. - Fournier, J. M. - Hoeller, P. (2018): Public Finance Structure and Inclusive Growth. OECD Economic Policy Paper 2018/25.

Darvas, Z. (2016): Brexit Vote Boosts Case for Inclusive Growth. Bruegel blog. https://bruegel.org/2016/07/ brexit-vote-boosts-case-for-inclusive-growth/, accessed 3 October, 2020.

Darvas, Z. (2019): EU Enlargement 15th Anniversary: Upward Steps on the Income Ladder. Bruegel blog. http://bruegel.org/2019/04/eu-enlargement-15th-anniversary-upward-steps-on-the-income-ladder/, accessed 3 October, 2020.

Darvas, Z. - Efstathou, K. (2016): Income Inequality Boosted Trump Vote. Bruegel blog. https://bruegel. org/2016/11/income-inequality-boosted-trump-vote/, accessed 3 October, 2020.

Darvas, Z. - Midões, C. (forthcoming): Wealth Distribution and Social Mobility. Eurofound Research Report.

Darvas, Z. - Wolff, G. B. (2014): Europe's Social Problem and its Implications for Economic Growth. Bruegel Policy Brief 2014/03. https://bruegel.org/2014/03/europes-social-problem-and-its-implicationsfor-economic-growth/, accessed 3 October, 2020.

Darvas, Z. - Wolff, G. B. (2016): An Anatomy of Inclusive Growth in Europe. Bruegel Blueprint 26. https:// bruegel.org/2016/10/an-anatomy-of-inclusive-growth-in-europe/, accessed 3 October, 2020.

Diamond, P. - Saez, E. (2011): The Case for a Progressive Tax: From Basic Research to Policy Recommendations. Journal of Economic Perspectives 25(4): 165-190.

European Commission. (2012): The Quality of Public Expenditures in the EU. Directorate-General for Economic and Financial Affairs Occasional Papers 125. https://ec.europa.eu/economy_finance/ publications/occasional_paper/2012/op125_en.htm, accessed 3 October, 2020.

European Commission. (2018a): Report on Public Finances in EMU 2017. Institutional Paper 069. https:// ec.europa.eu/info/publications/economy-finance/report-public-finances-emu-2017_en, accessed 3 October, 2020.

European Commission. (2018b): Taxation Trends in the European Union. https://ec.europa.eu/taxation customs/sites/taxation/files/taxation_trends_report_2018.pdf, accessed 3 October, 2020.

European Commission. (2020): Data on Taxation. https://ec.europa.eu/taxation_customs/business/ economic-analysis-taxation/data-taxation_en, accessed 3 October, 2020. 
Fershtman, C. - Murphy, K. M. - Weiss, Y. (1996): Social Status, Education, and Growth. Journal of Political Economy 104(1): 108-132.

Fuentes, J. R. - Leamer, E. E. (2019): Effort: The Unrecognized Contributor to US Income Inequality. NBER Working Paper No. 26421.

Galor, O. - Zeira, J. (1993): Income Distribution and Macroeconomics. The Review of Economic Studies 60(1): 35-52.

Garcia-Bernardo, J. - Fichtner, J. - Takes, F. W. - Heemskerk, E. M. (2017): Uncovering Offshore Financial Centers: Conduits and Sinks in the Global Corporate Ownership Network. Nature Scientific Reports 7: 6246.

Jaimovich, N. - Rebelo, S. (2017): Nonlinear Effects of Taxation on Growth. Journal of Political Economy 125(1): 323-352.

Kaldor, N. (1957): A model of Economic Growth. The Economic Journal 67(268): 591-624.

Keefer, P. - Knack, S. (2002): Polarization, Politics and Property Rights: Links Between Inequality and Growth. Public Choice 111(1-2): 127-154.

Kneller, R. - Bleaney, M. F. - Gemmell, N. (1999): Fiscal Policy and Growth: Evidence from OECD Countries. Journal of Public Economics 74(2): 171-190.

Mirrlees, J. A. (1971): An Exploration in the Theory of Optimum Income Taxation. The Review of Economic Studies 38(2): 175-208.

OECD. (2020a): Inclusive Growth. https://www.oecd.org/inclusive-growth/, accessed 3 October, 2020.

OECD. (2020b): Taxing Wages Dataset. https://stats.oecd.org/Index.aspx?DataSetCode=AWCOMP, accessed 3 October, 2020.

Okun, A. M. (1975): Equality and Efficiency: The Big Trade-off. Washington: Brookings Institution Press.

Owen, A. L. - Weil, D. N. (1998): Intergenerational Earnings Mobility, Inequality and Growth. Journal of Monetary Economics 41(1): 71-104.

Piketty, T. - Saez, E. (2013): A Theory of Optimal Inheritance Taxation. Econometrica 81(5): 1851-1886.

Rajan, R. G. (2011): Fault Lines: How Hidden Fractures Still Threaten the World Economy. Princeton: Princeton University Press.

Sapir, A. (2006): Globalization and the Reform of the European Social Model. Journal of Common Market Studies 44(2): 369-390.

Skott, P. (2013): Increasing Inequality and Financial Instability. Review of Radical Political Economics 45(4): 478-488.

Van Treeck, T. (2014): Did Inequality Cause the US Financial Crisis? Journal of Economic Surveys 28(3) 421-448.

Vandemoortele, M. (2009): Within-country Inequality, Global Imbalances and Financial Instability. Overseas Development Institute Research Report. https://www.odi.org/sites/odi.org.uk/files/odi-assets/ publications-opinion-files/5066.pdf, accessed 3 October, 2020.

Vtyurina, S. (2020): Effectiveness and Equity in Social Spending - The Case of Spain. International Monetary Fund Working Paper No. 20/16.

World Bank. (2020): Worldwide Governance Indicators. https://info.worldbank.org/governance/wgi/, accessed 3 October, 2020.

Open Access. This is an open-access article distributed under the terms of the Creative Commons Attribution 4.0 International License (https://creativecommons.org/licenses/by/4.0/), which permits unrestricted use, distribution, and reproduction in any medium, provided the original author and source are credited, a link to the CC License is provided, and changes - if any - are indicated. (SID_1) 